\title{
Immunization and Nutritional Status Towards Acute Respiratory Infection Among Toddlers
}

\author{
Rehana \\ Nursing Departement \\ Poltekkes Kemenkes Palembang \\ Palembang, Indonesia \\ rehana@ poltekkespalembang.ac.id \\ Corresponding author: rehana@poltekkespalembang.ac.id
}

\begin{abstract}
Complete basic immunization status must be obtained by toddlers, as well as good nutritional status that must be fulfilled for the growth and development of toddlers. This can increase the immunity and resilience of children under five against ARI events that are susceptible to infants. The purpose of this research is to find out the Relationship between Basic Immunization and Nutritional Status with ARI Occurrence in Toddlers Aged 1-5 Years at Merdeka Public Health Center Palembang Method: The design of this research is analytic with cross-sectional survey. This research was conducted at the Merdeka Public Health Center in Palembang. This research was conducted in August 2016. The population in this study were all toddlers (1-5 years) who went to the Merdeka Public Health Center in Palembang. The sample size was 105 respondents, which were obtained according to the inclusion and exclusion criteria with purposive sampling technique. The independent variables in this study were basic immunization and nutritional status, and the dependent variable in this study was the incidence of ARI. Data in this study were obtained by questionnaire and checklist sheet. The analysis in this study used univariate and bivariate ( Chi-Square test ) Results: There was a relationship between basic immunization $(p=0.026)$ and nutritional status $(p=0.035)$ with ARI events in under fives. Discussion: Basic immunization status that is complete and supported by good nutritional status is very good in the prevention of Acut Respiratory Infection (ARI) in infants. Health workers at the Puskesmas can provide health education to the community, especially mothers who have children under five to be able to complete basic immunization status and meet good nutrition for toddlers to prevent ARI. Conclusion: Basic immunization status that is complete and supported by good nutritional status is very good in the prevention of ARI in infants. Suggestion: Health workers in Puskesmas can provide health education to the community, especially
\end{abstract}

mothers who have todllers to be able to complete basic immunization status and meet good nutrition for toddlers to prevent ARI

Keywords: Basic Immunization, Nutrition Status, Acut Respiratory Infection, Toddler.

\section{INTRODUCTION}

The government recommends a program of activities in the field of public health including nutrition improvement, reduction of

maternal and infant mortality, the eradication of infectious diseases, the use and availability of clean water and to pitch range of essential drugs to achieve the Millennium Development Goals (MDGs) by 2015 [1]. According to the Environmental Health Program Policy Guidelines, environment-based disease is a pathological condition in the form of abnormalities or morphology of an organ caused by human interaction with everything around it that has the potential for disease. One environmentally based disease in Indonesia is always in the top 10 diseases that occur almost in all health centers in the Indonesia is Inspection Respiratory Akut ( ISPA ) [2]. The most contributing factor with ARI is nutritional status and immunization because poor nutrition can lead to lack of immune system and incomplete immunization can be easily attacked by ARI. Various studies have been conducted, nutritional status and immunization have meaningful relationships ter toward Acut Respiratory Infection (ARI) [3]. 
Goal of national development and projection of malnutrition in children under five, Indonesia in 2000 had malnutrition rates of $7.5 \%$ in 2001 from malnutrition in Indonesia amounted to $6.3 \%$ in 2002 from malnutrition in Indonesia by $8.0 \%$, on in 2003 malnutrition in Indonesia was $8.3 \%$ and in 2005 malnutrition in Indonesia was $8.8 \%$. Based on data from 2000 to 2005 the number of nutritional cases in Indonesia increased [7].

Immunization will increase body immunity. United Nations Childrens Funds (UNICEF) for three decades has been promoting vaccination programs for children, in developing countries, by providing Dipteria, Measles, Pertussis, Polio, Tetanus and TBC vaccination assistance the ratio of the risk of death of children who received the vaccine to those who did not receive the vaccine is 1: 9 [8].

Immunization is the process for making the body's immune defense system gainst microorganisms (bacteria and viruses) that can cause infection prior to microorganisms that have a chance to invade our bodies. With immunization our body will be protected from infection [4]. Immunization will increase the immunity of infants and children so that they are able to fight diseases that can be prevented by vaccines. Children who have been immunized when infected by germs, it will not transmit to brother, sister, or friends nearby. So, immunization is not only beneficial for yourself but also useful for preventing the spread to younger siblings, siblings and other children around them. Another benefit is that it can prevent several types of infectious diseases including ARI [5].

In addition to immunization, nutritional status also affects the health of children under five, the occurrence of disease infections has a reciprocal relationship. Poor nutrition appears as an important risk factor for ARI. Toddlers with poor nutrition will be more susceptible to ARI compared to toddlers with normal nutrition due to lack of endurance factors [6].

Nutrition is very important for growth, development and maintenance of body activities. Without adequate nutrition, the body will be susceptible to infectious diseases. The emergence of malnutrition is not only due to lack of food intake, but also disease. Children who get enough food but often suffer from illness can eventually suffer from malnutrition. Similarly, children who do not get enough food, their immune system will be weakened and will be susceptible to disease [7].

The World Health Organization (WHO) in the paper estimates that the incidence of acute respiratory infections (ARI) in developing countries with underfive mortality rates per 40 live births is $15 \%-20 \%$ per year in the toddler age group. According to WHO \pm 13 million children under five in the world die every year and most of these deaths are the main cause of death by killing \pm 4 million children under five every year [8].

Effective interventions or actions to reduce the increase in prevalence of ARI based on recommendations given by the Indonesian Pediatrician Association (IDAI) can be done by increasing the intake of nutrition and balanced nutrition and providing complete immunization according to schedule [9].

Prevention of ARI through efforts to improve health such as immunization, improvement of nutrition and improvement of the residential environment. Increasing even distribution of quality health services will also reduce morbidity and mortality due to ARI [1].

Prevention methods that are proven to be the most effective at this time are by administering measles and pertussis (DPT) immunization. With effective measles immunization about $11 \%$ of pneumonia deaths can be prevented and with pertussis immunization (DPT), $6 \%$ of pneumonia deaths can be prevented [6].

\section{METHODS}

The design used in this study is a cross-sectional analytic survey. This research was conducted at the Merdeka Public Health Center in Palembang. This research was conducted in August 2016.

The population in this study were all toddlers (1-5 years) who went to the Merdeka Public Health Center in Palembang. The sample size was 105 respondents which were obtained according to the inclusion and exclusion criteria by using purposive sampling technique.

The inclusion criteria of this study are

1) Toddlers aged cfcv1-5 years

2) Toddlers brought to Posyandu in the Work Area of Merdeka Public Health Center in Palembang.

The independent variable in this study is basic immunization and nutritional status, and the dependent variable in this study is the incidence of ARI. The data in thi sstudy were obtained by distributing questionnaires and checklist sheets. The analysis in this study used univariate and bivariate ( Chi-Square test). 


\section{RESULTS}

Table 1. Distribution of Respondent Characteristics at the Merdeka Public Health Center in Palembang, August 2016

\begin{tabular}{clccc}
\hline & Characteristics & $\mathrm{N}$ & $\%$ & the \\
\hline $\begin{array}{c}\text { Gender } \\
\text { 1. }\end{array}$ & Male & 47 & 44.8 & rejec \\
2. & Girl & 58 & 55.2 & relat \\
\hline Total & & 105 & 100 & in \\
\hline Age & & & & (O) \\
1. & 1 year & 16 & 15.2 & statu \\
2. & 2 years & 43 & 41 & Pale \\
3. & 3 years & 30 & 28.6 & \\
4. & 4 years & 13 & 12.4 & \\
5. & 5 years & 3 & 2,9 & \\
\hline Total & & 105 & 100 & \\
\hline
\end{tabular}

Tabel 2. Distribution of Respondent Characteristics at the Merdeka Public Health Center in Palembang, August 2016.

\begin{tabular}{|c|c|c|c|c|c|}
\hline \multirow{3}{*}{$\begin{array}{c}\text { Immunization } \\
\text { Status }\end{array}$} & \multicolumn{4}{|c|}{$\begin{array}{c}\text { Acut Respiratory Infection } \\
\text { (ARI) History }\end{array}$} & \multirow{3}{*}{ Total } \\
\hline & \multicolumn{2}{|c|}{ No ARI } & \multicolumn{2}{|c|}{ ARI } & \\
\hline & $\mathrm{N}$ & $\%$ & $\mathrm{~N}$ & $\%$ & \\
\hline Complete & 49 & 46.7 & 6 & 5.7 & 55 \\
\hline Incomplete & 36 & 34.3 & 14 & 13.3 & 50 \\
\hline Total & 85 & 81 & 20 & 19 & 105 \\
\hline \multicolumn{6}{|c|}{$\begin{array}{c}\mathrm{p} \text {-value }=0,026 \\
\text { OR }=1,237\end{array}$} \\
\hline
\end{tabular}

Tabel 3. Distribution of Nutrion Status for Acut Respiratory Infection (ARI) Events in Toddlers

\begin{tabular}{|c|c|c|c|c|c|}
\hline \multirow{3}{*}{$\begin{array}{c}\text { Nutritional } \\
\text { Status }\end{array}$} & \multicolumn{4}{|c|}{ ARI History } & \multirow{3}{*}{ Total } \\
\hline & \multicolumn{2}{|c|}{ No ARI } & \multicolumn{2}{|c|}{ ARI } & \\
\hline & $\mathrm{N}$ & $\%$ & $\mathrm{~N}$ & $\%$ & \\
\hline Well & 63 & 60 & 10 & 9.5 & 73 \\
\hline Less & 22 & 21 & 10 & 9.5 & 32 \\
\hline Total & 85 & 81 & 20 & 19 & 105 \\
\hline \multicolumn{6}{|c|}{$\begin{array}{c}\mathrm{p} \text {-value }=0,035 \\
\mathrm{OR}=0,797\end{array}$} \\
\hline
\end{tabular}

Table 1 shows that the majority of respondents were toddlers with a female gender of 58 $(55.2 \%)$. Meanwhile, the majority of respondents were 2 years of age as many as $43(41 \%)$.

Table 2 shows that the majority of respondents did not experience a history of ARI with either complete or incomplete

immunization status. Chi-Square test results showed that the p-value $=0.02650 .05$ which means that Ho was rejected. This means that there is a significant relationship between immunization status and ARI events in Merdeka Palembang Health Center 2016. Odd Ratio (OR) shows 1,237 which means that immunization status increases the number of non-ARI events in Merdeka Palembang Health Center 2016.

Table 3 shows that the majority of respondents did not experience a history of ARI events with good or poor nutritional status. Chi-Square test results showed that the $\mathrm{p}$-value $=0.035 \leq 0.05$ which means that Ho was rejected. This means that there is a significant relationship between nutritional status and ARI events in Merdeka Palembang Health Center 2016. Odd Ratio (OR) shows 0.797 which means that immunization status reduces the incidence of ARI in Merdeka Palembang Health Center 2016.

\section{DISCUSSION}

Immunization is immune relief efforts that are formed through the vaccinations that are beneficial to the $\mathrm{V}$ prevent some types of infectious diseases including respiratory diseases. Immunization $\mathrm{V}$ that can prevent ARI is V DPT and measles immunization. Infants and \%oddlers $\mathrm{V}$ who have complete immunization status $\mathrm{V}$ if suffering from ARI can be expected that 52 the development of the disease will not become more 4 segvere. Toddlers who have received complete 1 if immunity to certain diseases, so if there are germs that enter the body directly the body will form antibodies against these germs. Inadequate immunization is a risk factor that can increase the incidence of ARI, so the immunized child factor greatly determines the high incidence of ARI. Infantry is said to have received complete immunization if it has received the immunization that should have been obtained in accordance with the deadline. Not getting immunized against measles means that the child is more at risk of 69eveloping ARI and even death due to pneumonia. [1] 3 Q 5 search conducted by researchers shows that the thlajority of children who are not fully immunized do not experience significant ARI events. This can be caused by several factors such as immunity in infants. Immune is resistance to diseases, especially infections. The combination of cells, molecules and tissues that play a role in resistance to infection is called the immune system. The reaction dikoordin as $\mathrm{i}$ cells, molecules and materials against other known microbial immune response. The immune system is needed by the body to maintain its integrity against the dangers that can be caused by various substances in the environment [2]. B Alita with incomplete basic immunization history is often exposed to risk for ISPA 2.161 times larger than a toddler with complete basic immunization history. [10].

The risk factor for ARI is also often mentioned in the literature is the age factor. The relationship between 
children's age and ARI is easily understood, because the younger the toddler age, the lower the body's endurance. Children less than two years old have a higher risk of developing ARI. Children less than 2 years old are children who are very at risk of pneumonia. This is because children under 2 years of immunization are not yet perfect and the respiratory tract is relatively narrow [11]

These results are in line with the results of previous studies, namely by the existence of a complete basic immunization, the risk of ARI disease will be smaller [12]. When a baby or toddler who has been attacked by measles and survivors will get natural immunity against pneumonia as a complication of measles. Most ARI deaths originate from a type of ARI that develops from diseases that can be prevented by immunizations such as diphtheria, pertussis, measles. Thus, increasing basic immunization coverage will play a major role in efforts to eradicate ARI. Likewise with the results of research which states that the provision of basic immunization can prevent various types of infectious diseases. Considering the high infant and under-five mortality rates caused by ARI, the provision of complete basic immunization of disease development will not become more severe [13]. The results of this study are also consistent with research conducted by [14] and research conducted by [15] which shows that the basic status of immunization can affect the incidence of ARI in infants.

Acute Respiratory Infection (ARI) is an infection of one or more respiratory tracts [16]. In general there are three risk factors for ARI events in infants, namely: environmental factors, toddler factors, and parental behavior factors. Factors under five, especially the nutritional status is the most influential factor compared to other factors. Toddlers are an age group that is still vulnerable to health and nutrition problems [17]. Nutritional status is believed to affect a person's immune system, especially toddlers. Poor nutritional status can cause mucosal damage that serves as the primary immune system, thereby increasing the risk of disease [18].

Malnutrition can result in weight loss, growth disturbance, decreased immunity and damage to the mucosa, including the respiratory mucosa. Decreased immunity and mucosal damage play a major role in the pathogenesis of non-pneumonia ARI . This will make it easier for infectious agents to enter the body's defense system [19]. This study proved the theory of The Immune System is Bridge of Life in [20], which has been modified, stating the status of nutrition is an intermediate factors can affect the resistance of the body of a person.
The results of this study are consistent with the results of research conducted by [21] namely that of $36 \%$ of under-fives underweight nutritional status, $64 \%$ of under-fives with good nutritional status, $32 \%$ of underfives lacking endurance, and $68 \%$ of under-fives having resistance to ARI non-pneumonia have a relationship significant impact on ARI.

The results of research conducted by [22] also indicate that good nutritional status is very influential on the incidence of recurrent ARI. In this study explains that toddlers with malnutrition status can be prevented early on during the pregnancy period by doing routine pregnancy checks. Poor nutrition in infants can occur due to disorders during pregnancy such as nutritional deficiencies in pregnant women.

Many other certifications also prove that nutritional status is related to ARI. One of the studies conducted in Israel which stated that the improvement of antenatal methods and nutritional status can reduce the risk of pneumonia in children [23]. Micronutrients such as nutrients can reduce ARI [24].

\section{CONCLUSION}

Basic immunization status that is complete and supported by good nutritional status is very good in the prevention of Acut Respiratory Infection (ARI) in todler.

\section{SUGGESTIONS}

Health workers at the Puskesmas can provide health education to the community, especially mothers who have children under five to be able to complete basic immunization status and meet good nutrition for toddlers to prevent Acut Respiratory Infection (ARI).

\section{REFERENCES}

[1] Moh R. Pedoman Pemberantasan Akut Infeksi Saluran Pernafasan (ISPA) dan Pneumonia pada Balita,. 2012.

[2] Lestari Y. Berbasis Lingkungan Penyakit, Faktor Terkait Berbasis Lingkungan Penyakit. 2013.

[3] Lakoro F. Hubungan Status Imunisasi Acara ARI di Balita. Univ Negeri Gorontalo 2013.

[4] Marmi, Rahardjo K. Asuhan Neonatus Bayi, Balita, dan Anak Prasekolah. Yogyakarta: Pustaka Belajar; 2012.

[5] IDIA. Immunization Important to Prevent Dangerous Diseases. 2013.

[6] Maryunani A. Ilmu Kesehatan Anak di Kebidanan. 2010

[7] Asmidayanti S, Kasmita, Yuliana. Hubungan Status Gizi Dengan Morbiditas Ispa Anak Usia Balita Di Desa Tanjung Tanah Kecamatan Danau Kerinci Kabupaten Kerinci. Pendidik Kesejateraan Kel FT Univ Negeri Padang 2012:115.

[8] Mansbridge J. Skin substitutes to enhance wound healing. Expert Opin Investig Drugs 1998;7:803-9.

[9] IDAI. Immunization is Important to Prevent Dangerous 
Diseas. 2013.

[10] LM Hidayatullah, Helmi Y., Aulia. Relationship Between Completeness Immunization Basics and Frequency of Acute Respiratory Infections (ARI) on Toddler Coming b erkunjung to PHC Sekip Palembang in 2014. J Med Heal 2014; Vol 3 No.3.

[11] Hidayatullah LM, Helmi Y, Aulia H. Hubungan Antara Kelengkapan Imunisasi Dasar dan Frekuensi Infeksi Saluran Pernapasan Akut ( ISPA ) pada Balita yang Datang Berkunjung ke Puskesmas Sekip Palembang 2014. J Kedokt Dan Kesehat 2016;3:182-93.

[12] Agussalim. Hubungan Pengetahuan, Status Imunisasi dan Keberadaan Perokok dalam Rumah dengan Penyakit Infeksi Saluran Pernapasan Akut pada Balita di Puskesmas Peukan Bada Kabupaten Aceh Besar. J Ilm Stikes U'Budiyah 2012;1:1-11.

[13] Malik I, Machfoedz I. Cakupan Imunisasi Dasar dengan Kejadian ISPA pada Balita Usia 1-3 Tahun di Wilayah Puskesmas Wonosari 1 Kabupaten Gunungkidul The Scope of Basic Immunization and Acute Respiratory Infections ( ARIs ) in Toddlers Aged 1-3 Years in The Region of Puskesmas Wonosari 1 Gunungkidul District n.d.:53-7.

[14] Kai MW, Tomayahu MB, Anggraini R. The relationship of low birth weight with acute respiratory infection ( ari ) on toddlers in telaga health care clinic Of gorontalo distric n.d.:1-9.

[15] Malik I, Mahfoedz I, Mahfud. Cakupan Imunisasi Dasar dengan Kejadian ISPA pada Balia Usia 1-3 Tahun di Wilayah Puskesmas Wonosari 1 Kabupaten Gunungkidul. J Ners Dan Kebidanan Indones 2015;3 (1), p.

[16] Nelhon W. Ilmu Kesehatan Anak. 2011.

[17] Maitatorum E. KEJADIAN ISPA ANAK BALITA DI PERKAMPUNGAN KUMUH KOTA SURAKARTA 2001:21-30.

[18] Hayati S, Keperawatan FI. GAMBARAN FAKTOR PENYEBAB INFEKSI SALURAN PERNAFASAN AKUT ( ISPA ) PADA BALITA DI PUSKESMAS PASIRKALIKI KOTA 2014:62-7.

[19] Mandar P. Unnes Journal of Public Health 2016;5.

[20] Coles CL, Fraser D, Givon-lavi N, Greenberg D. Nutritional Status and Diarrheal Illness as Independent Risk Factors for Alveolar Pneumonia Nutritional Status and Diarrheal Illness as Independent Risk Factors for Alveolar Pneumonia 2005. https://doi.org/10.1093/aje/kwi312.

[21] Shifa M, Arifin S, Yuliana I, Studi P, Dokter P, Kedokteran $\mathrm{F}$, et al. HUBUNGAN STATUS GIZI DENGAN KETAHANAN TERHADAP ISPA NON-PNEUMONIA PADA BALITA DI PUSKESMAS PEKAUMAN BANJARMASIN n.d.:263-70.

[22] No Title 2009:1-12

[23] Lakoro F. Relationship of Immunization Status to ARI Events in Toddlers. Fac Heal Sci Gorontalo State Univ 2013.

[24] Abdullah B. Mingguan Serentak Suplementasi Besi dan Seng terkait dengan Menurunkan Morbiditas Akibat Diare dan Menurunkan Akut Infeksi Saluran Pernapasan pada Bayi Bangladesh. J Nutr 2009. 